$\underline{\text { Review Article }}$

\title{
AN IMPLICATION OF ACTINOMYCETES ON HUMAN WELL-BEING: A REVIEW
}

\author{
ALI MOHAMMED ABDULLAH BAWAZIR ${ }^{1}$, PALAKSHA², MANJULA SHANTARAM²*
}

${ }^{1}$ Department of Studies and Research in Microbiology, Post Graduate Centre, Mangalore University, Jnana Kaveri, Chikka Aluvara, Kodagu 571232, Karnataka, India, ${ }^{2}$ Department of Studies and Research in Biochemistry, Post Graduate Centre, Mangalore University, Jnana Kaveri, Chikka Aluvara, Kodagu 571232, Karnataka, India

Email: manjula59@gmail.com

Received: 03 Jan 2019 Revised and Accepted: 29 Mar 2019

\section{ABSTRACT}

This review conceptualizes about the actinomycetes and its contribution to human health by playing a key role as bioactive secondary metabolites, such as enzymes, antibiotics and pigments, leading to their diverse applications and use in various industries. These searches have been uncommonly successful, and around $66 \%$ of naturally happening antibiotics, including many medically important, have been isolated from actinomycetes. The speedy occurrence of antimicrobial resistance among pathogens has led to a renewed interest to search for novel antimicrobial agents, but these antibiotics are not enough for the treatment of all diseases because there is a berserk requirement for a novel actinomycetes to combat against the antibiotic-resistant strains of pathogenic microorganisms, which are quickly expanding bit by bit. Actinomycetes are the important providers to the pharmaceutical and other industries and are well known for their capacity to produce secondary metabolites many of which are active against pathogenic microorganisms.

Keywords: Actinomycetes, Antibiotics, Natural pigments, Enzymes

(C) 2019 The Authors. Published by Innovare Academic Sciences Pvt Ltd. This is an open access article under the CC BY license (http://creativecommons.org/licenses/by/4.0/) DOI: http://dx.doi.org/10.22159/ijpps.2019v11i5.31829

\section{INTRODUCTION}

The presence of actinomycetes has been known for over hundred years. For much of the time they were seen as a foreign group of organisms with an attraction to both bacteria and fungi. However, the study of their fine structure and chemical composition started in the 1950s, having confirmed their prokaryotic nature. They now create the order actinomycetales and their removal from the mycologists, has ruined the effective reach. Their difference in status paralleled that of the blue-green growth to the cyanobacteria but it was accepted more rapidly and less bitterly. It is not easy to give a short, accurate definition of actinomycetes. They are frequently described as bacteria which have the ability to form branching hyphae at some stage of their development. However, this attribute is unconvincing and it often requires the imagination to believe in it [1].

The name "actinomycetes" was derived from Greek "atkis" (a ray) and "mykes" (fungus) and has features of both bacteria and fungi [2] Actinomycetes are soil organisms which have features common to bacteria and fungi and however possess sufficient distinctive features to delimit them into a distinct group. They were initially erroneously classified as fungi since they have true aerial hyphae and form spores, both of which are thought to be fungal characteristics [3]. Actinomycetes are characterized as microscopic organisms that can shape spreading hyphae at some phase of their advancement [4]. They are characterized by having a high guanine and cytosine content in their deoxyribonucleic acid [5]. The actinomycetes are a group of microbes which possess many significant and interesting features. They have given many important bioactive compounds of high commercial value and continue to be routinely screened for new bioactive substances.

These searches have been uncommonly successful, and around $66 \%$ of naturally happening antibiotics, including many of medical significance, have been isolated from actinomycetes [6]. One result of intense screening programs carried out over the past several years is that there is a developing issue of "rediscovery" of definitely known bioactive compounds [7]. This pattern appears to suggest that the effortlessly open microorganisms in soil had been depleted and there is a need to look for unutilized microorganisms from unexplored sources [8].

One way to approach with this issue is to extend the source of actinomycetes via ecological evaluations of environments other than earthly soils. There is also a growing interest in the nonstreptomycete actinomycetes as sources of novel compounds [7]. It is likely that the assorted variety of secondary metabolites depends pretty much on the isolation source, viz. the environment of the producers [8]. Based on the above beliefs, new actinomycetes strains that create active compounds have been as of late removed from novel sources including saline, sea, mangrove woodlands and specialty natural surroundings, for example, caves, beehives, pristine forests, lakes, rivers and other wetlands [9-12], to cope with the demand for new pharmaceutical compounds and to resist the antibiotic-resistant pathogens.

Goals of novel actinomycetes research towards contribution to the human health

The war continues between antibiotics and resistant bacteria. More the scientists produce new and effective antibiotics, more frequent will be the bacteria changing their genetic mutations and adjusting their defenses, according to the components of the new antibody and win it, every time. To solve the problem of antimicrobial resistance there is a need for the discovery of new drugs, which is a critical element in a coordinated response to antimicrobial resistance. The resistance of bacteria to antibiotics is one of the global health and economic problems, prompting researchers to look for new antibodies to overcome resistant bacterial strains that increase mortality and epidemics. Health experts estimate that nearly 90,000 people die each year from antibiotic-resistant bacteria in the United States, and hospital-acquired disease develops in more than 2 million people annually, and that three-quarters of these occur as a result of at least one adverse common antibiotic. Antibiotic-resistant bacteria make the patient stay in the hospital for a long time, increase the risk of disease and also increase direct economic costs of antibiotic-resistant bacteria. For example, the infection of Pseudomonas aeruginosa in hospitalized patients, costs \$ 74,040 , more than the treatment costs for a sensitive strain, ie. patients with Staphylococcus aureus methicillin resistance and may cost up to $\$ 4,000$ more than the cost of treating patients with an antibiotic-resistant $S$. aureus strain. The cost of treatment with multidrug-resistant TB bacteria is $\$ 180,000$ or more and the cost of treatment for sensitive strains is $\$ 2,000$. In general, the total cost associated with antibiotic-resistant bacteria is estimated at \$4-5 billion per year in the United States [1]. 
There is a post for new anti-infection agents to treat ailments via looking for different sources, for example, actinomycetes to confine crude anti-infection agents. Since, now $66 \%$ of the anti-infection agents utilized as a part of medication are recently separated from actinomycetes and numerous more are of therapeutic significance, having been secluded from it [6].

Screening of actinomycetes for the generation of new anti-infection agents has been seriously taken after a long time by researchers. Anti-microbials have been utilized as a part of numerous fields including agribusiness, veterinary and pharmaceutical industry. Actinomycetes can integrate various naturally dynamic optional metabolites, for example, anti-infection agents, herbicides, pesticides, hostile to parasites, and catalysts like cellulase and xylanase which are utilized as a part of waste treatment [14].

The proceeding with accomplishment of a biotechnologist in the hunt of microbial metabolites as antimicrobial mixes (anti-infection agents) is helpful in battling human, creature and plant illnesses for fortifying the conviction that microorganisms constitute a limitless supply of mixes with pharmacological, physiological, medicinal or rural applications [15].

Antibiotic drug discovery is an indispensable process to combat aggressive ability of pathogenic microorganisms and emerging infectious diseases against health and well-being of people throughout the world [16]. According to the updated and expanded data on natural products presented by Newman and Cragg [17], the utility of natural products as sources of novel structures is still alive and the anti-infective area depends on natural products and their structures. The natural products with pharmaceutical importance are largely produced from primary and secondary metabolism of plants and microorganisms. Microbial natural products have made an incredible contribution to the antibiotic drug discovery and development process over last seven decades [18]. Alexander Fleming's discovery of penicillin from a mold in 1928 and its subsequent progress into a medicine in the 1940s laid the foundation for development of microbial natural products as drugs $[19,20]$. Afterwards, according to Waksman's resulting reports of actinomycin, streptothricin and streptomycin in 1940, 1942 and 1943 respectively, actinomycetes was introduced as a source of antibiotics [21-23]. At the end of the 20 th century, diversified actinobacterial natural products had found wide utilization in clinical field as antibacterial, antifungal, antiparasitic, and anticancer agents [24]. According to Berdy [25], out of all studies of bioactive compounds of microbial origin, $45 \%$ are produced by actinomycetes. Moreover, $90 \%$ approximately of antibiotics utilized as drugs isolated from the actinomycetes and they are as yet being principal natural antibiotic producers [26]. Since the report of streptomycin from the strains of Streptomyces griseus, there has been a fast acceleration in antibiotic discovery from the genus Streptomyces (biggest genus of Actinobacteria). Subsequently, members of this genus have become renowned as a prime source of natural antibiotics $[27,28]$.

It has been evidenced by continuing production of string of commercially important antibiotics like daptomycin, erythromycin, fosfomycin, lincomycin, neomycin, streptomycin, and tetracycline from industrially-important members of the genus Streptomyces [29]. However, the possibility of novel antimicrobial leads from these special actinomycetes has as of late dwindled upon the rediscovery of known compounds [30] and the focus of current microbial drug discovery programs being reoriented toward other promising microbial resources. Other side of the coin, emergence of new infectious diseases and antibiotic resistance provoked in earlier infectious diseases has raised the need for novel antibiotics. Against this background, uncommon actinomycetes (non-streptomycetes) are by and by isolated from different habitats and genuinely examined for antibiotic discovery programs. The rare actinomycetes are generally viewed as strains of actinomycetes whose isolation frequency by traditional methods is significantly lesser than that of streptomycete strains [31]. According to Tiwari and Gupta [32], this non-streptomycete actinomycetes group include diverse bioactive secondary metabolite producing members under following genera: Actinomadura, Actinoplanes, Amycolatopsis, Dactylosporangium,
Kibdelosporangium, Kitasatospora, Microbiospora, Planomonospora, Planobispora, Salinispora, Streptosporangium, and Verrucosispora. The studies have furthermore been expanded by recent studies of bioactive compounds from individuals from other rare generators, Nonomuraea [33-35], Actinoalloteichus [36, 37], Pseudonocardia [3840] and Saccharothrix [41-43]. Furthermore, basic information about the habitats, physiology and secondary metabolite diversity of the rare actinomycetes have continuously increased [31]. Out of in excess of eight thousand antimicrobial products portrayed in the ABL database, $16 \%$ created by strains have a place with uncommon genera of actinomycetes [44]. Allocation of the novel actinomycetes has been observed to be wide in terrestrial and aquatic environments [31]. Isolation techniques have turned out to be vital as these uncommon actinomycetes utilize slow growth while quickly growing streptomycetes and fungal strains dominate in ordinary actinomycetes isolation methods. Different isolation methods have to be used for getting diverse actinomycetes from different sources. These methods use a variety of pretreatment techniques and enrichment techniques along with fipeoisolation medium improved with specfic antimicrobial agents [45]. In 2013, Tiwari and Gupta [46], have reviewed almost all the selective isolation methods that have been developed to date for isolation of rare actinomycetes. In fact, all the isolation methods are designed to favor the growth of rare actinomycetes while suppressing the growth of undesired microorganisms. In recent times, much care has been given to isolating rare actinomycetes from diverse previously unexplored common as well as uncommon extreme environments. Numerous rare actinomycetes have been isolated from variety of soil samples [31; 47-50], plant materials [51-53], marine sources [54-57], extreme saline zones [58], volcanic zones [59], hyper arids [60], glaciers [61,62], and much more. Therefore, a variety of uncommon actinomycetes accessible for current antimicrobial medication screening programs has increased. In the review article of Tiwari and Gupta [46] there are reports of isolation of uncommon actinomycetes from various natural habitats throughout the world. It is disclosed that a surprising assortment of uncommon actinomycetes colonize in diverse, previously unexplored natural habitats. Finally, rare actinomycetes are being detected as highly prospective sources of bioactive compounds. Ways have already been sketched to reach these rare microorganisms but steps should be taken with speci fic isolation strategies [16]. The developed disclosures of novel bioactive compounds from these uncommon actinomycetes (nonstreptomycetes) clearly opine that these organisms contribute to the antibiotic drug discovery programs [16].

\section{Importance of actinomycetes}

\section{Enzymes}

Different genera of Actinomycetes have been reported to create a wide cluster of potential industrial enzymes that can be utilized as a part of biotechnological applications and specific biomedical fields [63]. Proceeding advances in sequencing technology and bioinformatics apparatuses make it conceivable to think about the microbial enzyme production by utilizing proteomics and metaproteomics [64]. Microbial enzymes assume a key part as metabolic catalysts, promoting their different applications and use in different industries. The steady look for novel microbial enzymes has prompted an act of ad-lib in the industrial procedures which is the key pay off growth. Actinomycetes form a noteworthy group of microbial populaces in the soil, plant tissues, and marine environments. Actinomycetes produce numerous significant extracellular enzymes which can break down an assortment of organic materials. Enzymes produced by actinomycetes and used in various industries are cellulases, proteases, amylases, lipases, xylanases, chitinases, cutinases and pectinases (table 1). Actinomycetes distinguished from the extreme environments are known to be makers of novel enzymes with incredible industrial potential [65]. Actinomycetes have been consistently considered and utilized for the production of amylases, cellulases, proteases, chitinases, xylanases and pectinases. This audit production of industrially important enzymes by actinomycetes, their qualities and industrial uses (applications in biomedicine, food, cleanser, mash and paper, agribusiness, material, and waste administration) are commendable. 
Table 1: Significant enzymes produced by actinomycetes

\begin{tabular}{|c|c|c|c|}
\hline Enzyme & Producing strain & Industrial application & Reference \\
\hline Cellulase & Streptomyces ruber Thermobifida halotolerans & Detergent, Paper and pulp & [66-67] \\
\hline Protease & Streptomyces pactum and Streptomyces thermoviolaceus & Pharmaceutical, Leather, food and detergents & [68-69] \\
\hline Keratinase & Actinomadura keratinilytica and Streptomyces erumpens & Leather and detergents & [70] \\
\hline Amylase & Thermobifida fusca and Streptomyces avermitilis & $\begin{array}{l}\text { Paper, pulp, textile, food, brewing and distilling } \\
\text { industries }\end{array}$ & [71-72]. \\
\hline Xylanase & Streptomyces spp. And Actinomadura sp. & Paper, pulp and Animal feed & {$[73-74]$.} \\
\hline Lipase & Nocardiopsis alba Streptomyces exfoliates & $\begin{array}{l}\text { Detergent industries, foodstuff, oleochemical, } \\
\text { diagnostic settings and also in pharmaceutical fields }\end{array}$ & {$[75-76]$} \\
\hline Chitinase & $\begin{array}{l}\text { Streptomyces thermoviolaceus, Nocardiopsis prasina, } \\
\text { Streptomyces hygroscopicus and Streptomyces aureofaciens }\end{array}$ & Textile and Leather & {$[77-78]$} \\
\hline Pectinase & Streptomyces lydicus & Beverage and Textile & [79-81] \\
\hline $\begin{array}{l}\text { L- } \\
\text { asparaginase }\end{array}$ & $\begin{array}{l}\text { Streptomyces griseus, S. karnatakensis, S. albidoflavus and } \\
\text { Nocardia sp }\end{array}$ & $\begin{array}{l}\text { therapeutic agent in the cure of certain human } \\
\text { cancers, mostly in acute lymphoblastic leukemia }\end{array}$ & [82] \\
\hline
\end{tabular}

\section{Antibiotics}

The discovery of actinomycin was soon replaced by that of streptomycin which is most likely best known for its utilization in the control of tuberculosis. Numerous other medically helpful antibiotics are still being used. Although the greater part of these antibiotics began from streptomycetes, other genera, for example, Actinoplanes, Actinomadura, and Micromonospora, likewise deliver helpful or possibly valuable antibiotics. In spite of the fact that the rate of return has diminished as of late, new antibiotics and other valuable metabolites from actinomycetes are yet to be found. This will be represented by $\beta$-lactamase inhibitors, for example, clavulanic acid from Streptomyces clavuligerus [83], which has been economically produced to surmount bacterial resistance to existing $\beta$-lactam antibiotics. The capacity of actinomycetes to create valuable secondary metabolites stays amazing; in spite of the fact that the purposes behind this and biological importance of such products are as yet not clear [84]. Moreover, it is a continuous effort to look into new ecological housing for novel actinomycetes. Target coordinated screening is being utilized for screening of antibiotic-producing actinomycetes. Molecular biology methods have helped on a huge scale in finding new antibiotics from actinomycetes. The significance of actinomycetes in modern biosynthesis has catalyzed many parts of essential research on these microbes. The streptomycetes, are the most productive well spring of new antibiotics $[25,85,86]$. Actinomycetes are at present known to deliver more than 10,000 bioactive compounds, 7,600 of which have been isolated from streptomycetes and 2,500 from non-streptomycetes, prominently from the so-called rare actinomycetes [87].

In spite of this astounding productivity, it has been assessed that only tiny part of the aggregate number of antimicrobial compounds which actinomycetes can produce have been found to date [88]. Sacrificial numbers of bioactive microbial metabolites have appeared in table 1.1.
Antibiotics created by actinomycetes demonstrate an extensive variety of chemical assorted, as exhibited in table 1.2. It is obvious from this information that streptomycetes combine a different scope of antibiotics; it is likewise realized that particular basic sorts of antibiotics happen normally in these organisms, for example, ansalactam rings, macrocyclic lactones, polyether and cyclopeptide skeletons [25, 89]. However, certain particular structures are produced all the more every now and again by non-streptomycetes, for example, actinoplanes and amycolatopsis strains, which are rich sources of vancomycin-like glycopeptides [90]. For rare actinomycetes, there is a confirmation that taxonomic diversity can be utilized as a substitute for substance diversity among actinomycetes, particularly at the species level [91-93]. This implies that novel actinomycete ought to be a rich source of new bioactive compounds $[94,95]$. Thus, it promises well to devise specific isolation and characterization methodologies to secure delegates of rare actinomycete genera for pharmaceutical screening programs, a strategy which has been applied with some success [86, 87]. Rare actinomycete genera known to synthesize novel antibiotics, as exemplified by the genera Actinokineospora, Acrocarpospora, Actinosynnema, Amycolatopsis, Catenuloplanes, Cryptosporangium, Dactylosporangium, Kineosporia, Kutzneria, Microbispora, Microtetrasp ora, Nonomuraea, Thermomonospora, Pseudonocardia, Thermobifida, Saccharomonospora, Spirilliplanes, Streptosporangium and Virgosporan gium [45].

The significance of rare actinomycetes can be exhibited by the way that some of them are the source of commercially important antimicrobial products, as exemplified by erythromycin delivered by Saccharopolyspora erythraea [96], gentamicin by Micromonopsora purpurea [97, 98], rifamycin by Amycolatopsis mediterranei [99], teicoplanin by Actinoplanes teichomyceticus $[100,101]$ and vancomycin by Amycolatopsis orientalis [90].

Table 2: Estimated number of bioactive microbial metabolites as indicated by their producers and bioactivities [25]

\begin{tabular}{|c|c|c|c|c|c|}
\hline \multirow[t]{2}{*}{ Source } & \multicolumn{2}{|l|}{ Antibiotics } & \multicolumn{2}{|c|}{ Bioactive metabolites } & \multirow{2}{*}{$\begin{array}{l}\text { Total } \\
\text { bioactive } \\
\text { metabolites }\end{array}$} \\
\hline & $\begin{array}{l}\text { Total } \\
\text { antibiotics }\end{array}$ & $\begin{array}{l}\text { (with other } \\
\text { Activity) }\end{array}$ & $\begin{array}{l}\text { No antibiotic } \\
\text { activity }\end{array}$ & $\begin{array}{l}\text { (antibiotics plus other } \\
\text { bioactivies) }\end{array}$ & \\
\hline Bacteria: & 2900 & 780 & 900 & 1680 & 3800 \\
\hline Eubacteriales & 2170 & 570 & 580 & 1150 & 2750 \\
\hline Bacillus sp. & 795 & 235 & 65 & 300 & 860 \\
\hline Pseudomonas sp. & 610 & 185 & 185 & 370 & 795 \\
\hline Myxobacteria & 400 & 130 & 10 & 140 & 410 \\
\hline Cyanobacteria & 300 & 80 & 340 & 420 & 640 \\
\hline Actinomycetales: & 8700 & 2400 & 1400 & 3800 & 10100 \\
\hline Streptomyces sp. & 6550 & 1920 & 1080 & 3000 & 7630 \\
\hline Rare actinomycetes & 2250 & 580 & 220 & 800 & 2470 \\
\hline Fungi: & 4900 & 2300 & 3700 & 6000 & 8600 \\
\hline Microscopic fungi & 3770 & 2070 & 2680 & 4750 & 6450 \\
\hline Penicillium/Aspergillus & 1000 & 450 & 950 & 1400 & 1950 \\
\hline Basidiomycetes & 1050 & 200 & 950 & 1150 & 2000 \\
\hline Yeasts & 105 & 35 & 33 & 70 & 140 \\
\hline Slime moulds & 30 & 5 & 20 & 25 & 60 \\
\hline Total & 16500 & 5500 & 6000 & 11500 & 22600 \\
\hline
\end{tabular}


Table 3: Antibiotics isolated from actinomycete genera, as described in the antibiotic database of the Journal of Antibiotics [6]

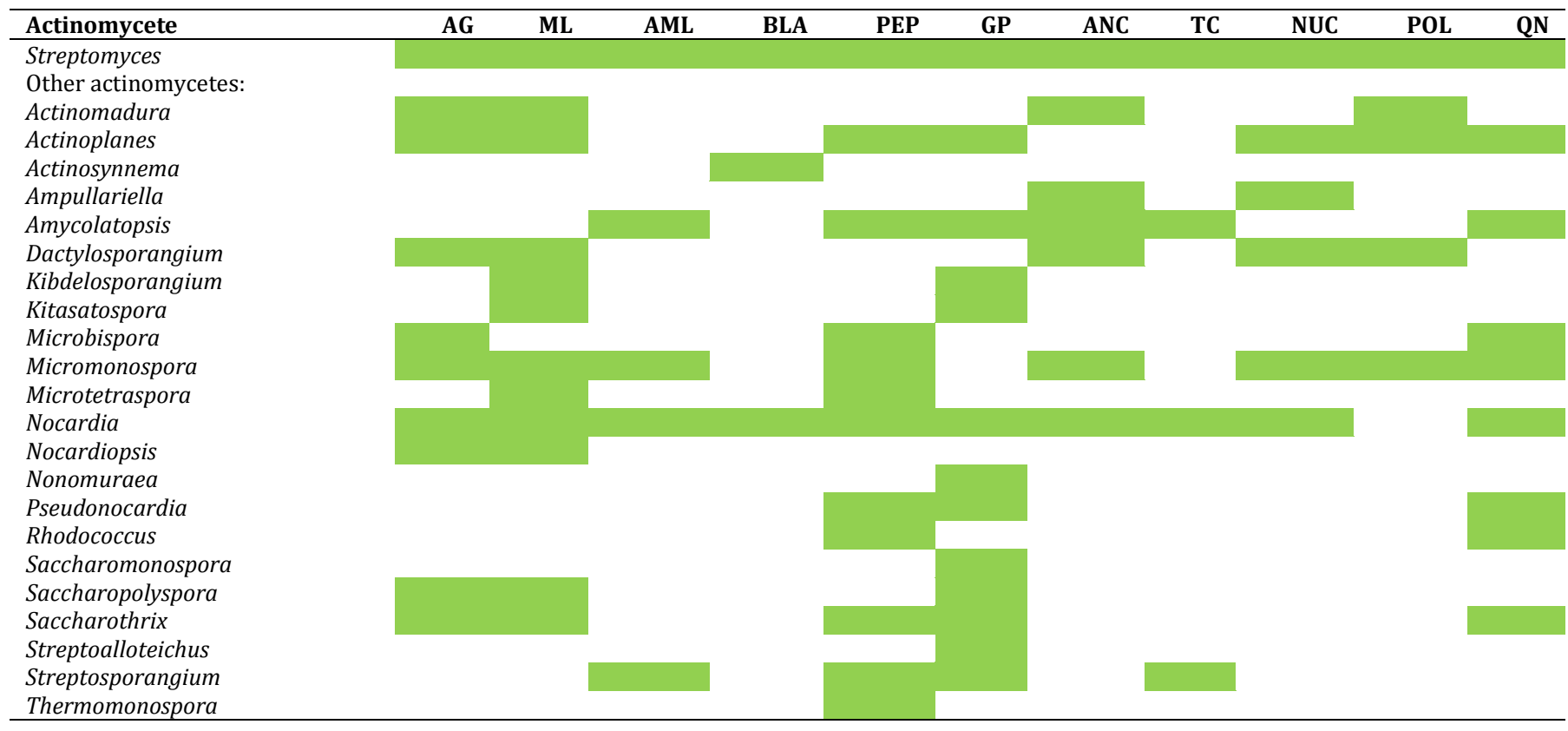

AG: aminoglycoside; ML: macrolide; AML: ansamacrolide; BLA: $\beta$-lactam; PEP: peptide; GP: glycopeptides; ANC: anthracycline; TC: tetracycline; NUC: nucleotide; $\square$ POL: polyene; QN: quinine: Production

\section{Natural pigments}

Several microscopic organisms will just produce their pigments under certain environmental conditions. Different species produce pigment as the colonies age or when a particular nutrient is available in the media. Pigments can help recognize microscopic organisms. For instance, a few microscopic organisms create watersoluble pigments which spread through the medium in which they develop. Others produce pigments that are soluble in fat. To decide this, one can expel some of a pigmented colony and shake it in oil. In the event that the oil becomes pigmented, the pigment is fat soluble. Natural pigments are a superior substitute to chemical dyes utilized in the industries and research centers. Out of the numerous types of Streptomyces available universally in the soil, $S$. coelicolor and $S$. violaceoruber produce an important red-blue anti-toxin actinorhodin and associated compounds like $\alpha-, \beta-, \varepsilon-$, actinorhodin collectively known as Actinorhodin-related "Blue Pigments". These pigments have an extensive variety of utilization in the scientific, medical and industrial sector [102]. Microorganisms can create distinctive colors, for example, those carotenoids, melanins, flavins, quinones, prodigiusens, monacens, violasin or indigo. The temperature of the nursery is the primary factor that relies upon the kind of microorganisms. Carotenoids are yellow-to-orange red pigments found in varieties of plants, bacteria, and fungi [103]. Recently, carotenoids are utilized commercially for nutraceuticals, beauty care products and pharmaceutical purposes [104]. Carotenoids can repress different sorts of cancer and can enhance immunity response [105]. It can likewise prevent life-related diseases due to its propitamin action and higher antioxidants capacity [106]. In future, through the genetic engineering of the microbial pathway, enzyme can produce a high measure of carotenoids. Since people started to experience the ill effects of different infections they started to look for anti-infection agents from microorganisms. Numerous bacterial infections caused by microorganisms have been resistant to antibiotics which has caused a major healthcare problem. So, there is a critical need to research into antibiotics against multidrug resistance inflammation.

Several different combination media have been suggested for isolation of actinomycetes, such as for example, starch casein agar [107], yeast malt extract agar [108], glycerol asparagine agar [109], tyrosine agar [110], glycerol yeast extract agar and starch yeast extract agar [111]. Determination of color or pigment production by the various isolates: for color determination, the media which had been prepared for morphological characterization was used. RAL Color Chart was used and color determination was done for mature sporulating aerial surface growth, the color of the substrate mycelium as seen from the reverse side of the plate and for diffusible pigments other than melanin. The color of the aerial surface growth was determined as white, gray, yellow, red, blue, green and violet. The presence of other soluble colors other than melanin pigmentation was determined if soluble colors other than brown or black was produced on any medium or if brown was distinctively modified with red, yellow, green, blue or violet. Actinomycetes are a productive source of secondary metabolites and by far most of these compounds are gotten from the single family Streptomyces. The actinomycetes have demonstrated their significance biotechnologically and industrially. The isolation and characterization of actinomycetes are an important approach to industrially important natural colors [112]. The isolation of actinomycetes from soil were also described by Selvameenal et al., [113] and the actinomycetes have a potential for pigment-producing ability along with antimicrobial activities. Many industries are using the natural pigment producing actinomycete. The study concluded that actinomycetes have the ability of diffusible pigment-production on different agar media, can open doors for food colors and beverage, in the pharmaceutical industry, and can be included in cosmetic industries.

\section{Biological control}

It is well understood that actinomycetes carry out various activities in soil: debasement of organic matter; hindrance or stimulation of different microorganisms and plant; conversion of the chemical compound, for example, herbicides and other horticulturally valuable compound and numerous different activities that can only be estimated [114]. Soil actinomycetes have fluctuating degrees of the inhibitory movement against particular fungi and by and large decrease soil fungal populace [115].

Streptomyces spp. has been appeared to have characteristics, which make them beneficial as biocontrol operators' soil-borne fungal plant pathogens. These qualities incorporate the production of various sort of secondary metabolites and biologically active substances of high commercial value such as enzymes which degrade the fungal cell divider straightforwardly and antibiotics. 
They are one of the major contributors to the biological buffering of the soil and have roles in the decomposition of organic matter conducive to crop production $[1,116]$.

\section{Plant growth enhancement}

The free-living actinomycetes has been in the improvement of plant development, where that more actinomycetes isolated from the rhizosphere of pine produced B vitamins, since mycorrhizae require these vitamins and are known to upgrade the growth of the plants. It was recommended that actinomycetes may in this indirectly contribute to plant development stimulation [117].

In another investigation, actinomycetes, added to the soil to control black rot of peanuts caused by Cylindrocladium crotalariae, did not increase control of the disease, but did, in some status measurably increase plant development [118].

\section{Biotechnology}

The consideration given to the actinomycetes in biotechnological applications is a characteristic consequence of the immense metabolic assorted variety of these living beings and their long relationship with the earth and needs of people. Other valuable activities of actinomycetes identified with biotechnology is their gene expression activity which is becoming an active research region [119].

\section{Waste management}

Wastes from food processing transactions contain the huge measure of starch [120]. Amylolytic actinomycetes may be utilized for bioconversion of such wastes. A few mesophilic streptomyces strains have been appeared to create amylase that hydrolyse starch and crude starch granules to maltose [121]. The amylases of thermophilic actinomycete have more mercantile potential than those of mesophilic Streptomyces e. g. Thermoactinomyces vulgaris is a good producer of a heat stable, highly active amylase.

Cyanide and other dangerous metals are produced on the industrial scale for use in the metal extraction, electroplating, and steel industry. In nature cyanide can be acclimatized or detoxified by plants. Certain microorganisms likewise can decompose cyanide to formamide, ammonia and carbon dioxide or cyaloalanine. Streptomyces lavendulae is observed to be a degrader of cyanide. It has a rhodanase enzyme that transfers sulfur from sodium thiosulphate to cyanide, forming thiocyanate [122]. Actinomycetes incorporate an extensive variety of mesophilic and thermophilic strains which break down lignocellulosic plant sediment [123]. Members of many species included have the potential for use in the bioconversion of under-used rural and urban wastes into high worth chemical products [124].

\section{CONCLUSION}

Actinomycetes are of great importance since they have the ability to contribute to human well-being through the production of antimicrobial agents and other industrial products like enzymes, drugs and natural pigments. Actinomycetes are at present known to deliver more than 10,000 bioactive compounds, 7,600 of which have been isolated from streptomycetes and 2,500 from nonstreptomycetes, prominently from the so-called rare actinomycetes.

\section{AUTHORS CONTRIBUTIONS}

All the authors have contributed equally

\section{CONFLICT OF INTERESTS}

\section{Declared none}

\section{REFERENCES}

1. Gottlieb D. General consideration and implications of the actinomycetales. In: Actinomycetales, characteristics and practical importance, Academic Press: London and New York; 1973. p. 1-10.

2. Das S, Lyla PS, Khan SA. Distribution and generic composition of culture-able marine actinomycetes from the sediments of Indian continental. Bengal Chinese J Oceanol Limnol 2008; 26:166-77.
3. Lechevalier HA, Lechevalier MP. Biology of actinomycetes. Ann Rev Microbiol 1967;21:71-99.

4. Goodfellow M, Williams ST. Ecology of actinomycetes. Ann Rev Microbiol 1983;37:189-216.

5. Stackebrandt E, Goebel BM. Taxonomic note: a place for DNADNA re-association and 16s $r$ RNA sequence analysis in the present species definition in bacteriology. Int J Syst Bacteriol 1994;44:846-9.

6. Okami Y, Hotta K. Search and discovery of new antibiotics in actinomycetes in Biotechnology. Edited by M Goodfellow, ST Williams, M Mordarski. London: Academic Press; 1988. p. 3367, 89-210.

7. Nolan RD, Cross T. In: Actinomycetes in Biotechnology. Goodfellow M, Williams ST, Mordarski M. Eds. Academic Press: London; 1988. p. 1-32.

8. Igarashi Y. Screening of novel bioactive compounds from plantassociated actinomycetes. Actinomycetol 2004;18:63-6.

9. Mukku VJ, Speitling M, Laatsch H, Helmke E. New butenolides from two marine streptomycetes. J Nat Prod 2000;63:1570-2.

10. Mitra A, Santra SC, Mukherjee J. Distribution of actinomycetes, their antagonistic behavior and the physicochemical characteristics of the world's largest tidal mangrove forest. Appl Microbiol Biotechnol 2008;80:685-95.

11. Promnuan Y, Kudo T, Chantawannakul P. Actinomycetes isolated from beehives in Thailand. World J Microbiol Biotechnol 2009;25:1685-9.

12. Radhakrishnan M, Suganya S, Balagurunathan R, Kumar V. Preliminary screening for antibacterial and antimycobacterial activity of actinomycetes from less explored ecosystems. World J Microbiol Biotechnol 2010;26:561-6.

13. Mohammed AM. Antibiotics: bacterial resistance to antibiotics. Ammaan Jordan 2011;358:135-8.

14. Oskay M, Same A, Azeri C. Antibacterial activity of some actinomycetes isolated from farming soils of turkey. Afr J Biotechol 2004;3:441-6.

15. Vandemme EJ. Biotechnology of industrial antibiotics. Dekker Series, Marcel Dekker Inc, New York 1948;22:3-42.

16. Jose PA, Jebakumar SRD. Non-streptomycete actinomycetes nourish the current microbial antibiotic drug discovery. FMICB 2013;4:240

17. Newman DJ, Cragg GM. Natural products as sources of new drugs over the $30 \mathrm{y}$ from 1981 to 2010. J Nat Prod 2012;75:311-35.

18. Demain AL, Sanchez S. Microbial drug discovery: $80 \mathrm{y}$ of progress. J Antibiot 2009;62:5-16.

19. Fleming A. On the antibacterial action of cultures of penicillium, with special reference to their use in the isolation of $B$. influenzae. Br J Exp Pathol 1929;10:226-36.

20. Chain E, Florey HW, Gardner AD, Heatley NG, Jennings MA, OrrEwing J, et al. Penicillin as a chemotherapeutic agent. Lancet 1940;2:226-8.

21. Waksman SA, Woodruff HB. Bacteriostatic and bacteriocidal substances produced by soil actinomycetes. Proc Soc Exp Biol 1940;45:609-14.

22. Waksman SA. Production and activity of streptothricin. J Bacteriol 1943;46:299-310.

23. Comroe JH Jr. Pay dirt: the story of streptomycin. I: from Waksman to Waksman. Retrospectroscope Am Rev Respir Dis 1978;117:773-81.

24. Butler MS. The role of natural product chemistry in drug discovery. J Nat Prod 2004;67:2141-215.

25. Berdy J. Bioactive microbial metabolites. J Antibiot 2005;58:1-26.

26. Hamaki T, Suzuki M, Fudou R, Jojima Y, Kajiura T, Tabuchi A, et al. Isolation of novel bacteria and actinomycetes using soilextract agar medium. J Biosci Bioeng 2005;99:485-92.

27. Jose PA, Santhi VS, Jebakumar SRD. Phylogenetic-affiliation, antimicrobial potential and PKS gene sequence analysis of moderately halophilic Streptomyces $s p$. inhabiting an Indian saltpan. J Basic Microbiol 2011;51:348-56.

28. Mohamed SH, Galal AM. Identification and antiviral activities of some halotolerant streptomycetes isolated from Qaroon Lake. Int J Agric Biol 2005;5:747-53.

29. Mahajan GB, Balachandran L. Antibacterial agents from actinomycetes-a review. Front Biosci 2012;E4:240-53. 
30. Koehn FE, Carter GT. The evolving role of natural products in drug discovery. Nat Rev Drug Discovery 2005;4:206-20.

31. Seong CN, Choi JH, Baikm KS. An improved selective isolation of rare actinomycetes from forest soil. J Microbiol 2001;39:17-23.

32. Tiwari K, Gupta RK. Rare actinomycetes: a potential storehouse for novel antibiotics. Crit Rev Biotechnol 2012;32:108-32.

33. Beltrametti F, Lazzarini A, Brunati C, Marazzi A, Jovetic S, Selva E, et al. Production and characterization of mono-chlorinated and dechlorinated A40926 derivatives. J Antibiot 2003;56:773-82.

34. Jose PA, Jebakumar SRD. Phylogenetic diversity of actinomycetes culturedfrom coastal multipond solar saltern in Tuticorin, India. Aquat Biosyst 2012;8:23.

35. Flatt PM, Wu X, Perry S, Mahmud T. Genetic insights into pyralomicin biosynthesis in Nonomuraea spiralis IMC A-0156. J Nat Prod 2013;76:939-46.

36. Fu P, Liu P, Li X, Wang Y, Wang S, Hong K, et al. Cyclic bipyridine glycosides from the marine-derived actinomycete Actinoalloteichus cyanogriseus WH1-2216-2216. Org Lett 2011;13:5948-51.

37. Wang XJ, Zhang J, Wang JD, Qian PT, Liu CX, Xiang WS. Novel cyclopentenone derivatives produced by a rare actinobacterial strain Actinoalloteichus nanshanensis sp. nov. NEAU 119. Nat Prod Res 2013. Doi:10.1080/14786419.771349.

38. Oh DC, Poulsen M, Currie CR, Clardy J. Dentigerumycin: a bacterial mediator of an ant-fungus symbiosis. Nat Chem Biol 2009;5:391-3.

39. Barke J, Seipke RF, Grüschow S, Heavens D, Drou N, Bibb MJ, et al. A mixed community of actinomycetes produce multiple antibiotics for the fungus farming ant Acromyrmex octospinosus. BMC Biol 2010;8:109.

40. Carr G, Derbyshire ER, Caldera E, Currie CR, Clardy J. Antibiotic and antimalarial quinones from fungus-growing ant-associated Pseudonocardia sp. J Nat Prod 2012;75:1806-9.

41. Murakami R, Shinozaki J, Kajiura T, Kozone I, Takagi M, Shin Ya $\mathrm{K}$, et al. Ammocidins, B, C and D, new cytotoxic 20-membered macrolides from Saccharothrix sp. AJ9571. J Antibiot 2009;62:123-7.

42. Aouiche A, Sabaou N, Meklat A, Zitouni A, Bijani C, Mathieu F, et al. Saccharothrix sp. PAL54, a new chloramphenicol-producing strain isolated from a saharan soil. World J Microbiol Biotechnol 2012;28:943-51.

43. Nakae K, Kurata I, Kojima F, Igarashi M, Hatano M, Sawa R, et al. Sacchathridine, A, a prostaglandin release inhibitor from Saccharothrix sp. J Nat Prod 2013;76:720-2.

44. Lazzarini A, Cavaletti L, Toppo G, Marinelli F. Rare genera of actinomycetes as potential producers of new antibiotics. Antonie Van Leeuwenhoek 2001;79:399-405.

45. Hayakawa H. Studies on the isolation and distribution of rare actinomycetes in soil. Actinomycetologica 2008;22:12-9.

46. Tiwari K, Gupta RK. Diversity and isolation of rare actinomycetes: an overview. Crit Rev Biotechnol 2013;39:256-94.

47. Gu Q, Paœciak M, Luo H, Gamian A, Liu Z, Huang Y. Ruania albidiflava gen. nov., sp. nov., a novel member of the suborder micrococcineae. Int J Syst Evol Microbiol 2007;57:809-14.

48. Li WJ, Xu P, Schumann P, Zhang YQ, Pukall R, Xu LH, et al. Georgenia ruanii sp. nov., a novel actinobacterium isolated from forest soil in Yunnan (China), and emended description of the genus georgenia. Int J Syst Evol Microbiol 2007;57:1424-8.

49. Li J, Zhao GZ, Huang HY, Zhu WY, Lee JC, Kim CJ, et al. Pseudonocardia rhizophila sp. nov., a novel actinomycete isolated from a rhizosphere soil. Antonie Van Leeuwenhoek 2010;98:77-83.

50. Ara I, Bakir MA, Hozzein WN, Kudo T. Population morphological and chemotaxonomical characterization of diverse rare actinomycetesin the mangrove and medicinal plant rhizosphere. Afr J Microbiol Res 2013;7:1480-8.

51. Qin S, Li J, Chen HH, Zhao GZ, Zhu WY, Jiang CL, et al. Isolation, diversity, and antimicrobial activity of rare actinobacteria from medicinal plants of tropical rain forests in Xishuangbanna, China. Appl Environ Microbiol 2009;75:6176-86.

52. Janso JE, Carter GT. Biosynthetic potential of phylogenetically unique endophytic actinomycetes from tropical plants. Appl Environ Microbiol 2010;76:4377-86.

53. Zhao GZ, Li J, Huang HY, Zhu WY, Zhao LX, Tang SK, et al. Pseudonocardiaartemisiae sp. nov, isolated from surface- sterilized Artemisia annua L. Int J Syst Evol Microbiol 2011;61:1061-5.

54. Zhang $\mathrm{H}$, Lee $\mathrm{YK}$, Zhang $\mathrm{W}$, Lee HK. Culturable actinobacteria from the marine sponge Hymeniacidon perleve: isolation and phylogenetic diversity by $16 \mathrm{~S}$ rRNA gene-RFLP analysis. Antonie Van Leeuwenhoek 2006;90:159-69.

55. Sun W, Dai S, Jiang S, Wang G, Liu G, Wu H, et al. Culture-dependent and culture-independent diversity of actinobacteria associated with the marine sponge Hymeniacidon perleve from the South China Sea. Antonie Van Leeuwenhoek 2010;98:65-75.

56. Radhakrishnan M, Balagurunathan R, Selvakumar N, Doble M, Kumar V. Bioprospecting of marine derived actinomycetes with special reference to antimycobacterial activity Indian. J Geo Marine Sci 2011;40:407-10.

57. Goodfellow M, Stach JE, Brown R, Bonda AN, Jones AL, Mexson $\mathrm{J}$, et al. Verrucosispora maris sp. nov., a novel deep sea actinomycete isolated from a marine sediment which produces abyssomicins. Antonie Van Leeuwenhoek 2012;101:185-93.

58. Jose PA, Jebakumar SRD. Phylogenetic appraisal of antagonistic, slow growing actinomycetes isolated from hypersaline inland solar salterns at sambhar salt lake, India. Front Microbiol 2013;4:190.

59. Lee DW, Lee SD. Allocatelliglobosispora scoriae gen. nov, sp. nov, isolated from volcanic ash. Int J Syst Evol Microbiol 2011;61:264-70.

60. Okoro CK, Brown R, Jones AL, Andrews BA, Asenjo JA Goodfellow $\mathrm{M}$, et al. Diversity of culturable actinomycetes in hyper-arid soils of the Atacama Desert, Chile. Antonie Van Leeuwenhoek 2009;95:121-33.

61. Reddy GSN, Pradhan S, Manorama R, Shivaji S. Cryobacterium roopkundensesp. nov., a psychrophilic bacterium isolated from glacial soil. Int J Syst Evol Microbiol 2010;60:866-70.

62. Zhang DC, Schumann P, Redzic M, Zhou YG, Liu HC, Schinner F, et al. Alpinus sp. nov., a psychrophilic actinomycete isolated from alpine glacier cryoconite. Int J Syst Evol Microbiol 2012;62:445-50.

63. Nawani N, Aigle B, Mandal A, Bodas M, Ghorbel S Actinomycetes: role in biotechnology and medicine. BioMed Res Int 2013. http://dx.doi.org/10.1155/2013/687190

64. Pieper R, Huang ST, Suh MJ. Proteomics and metaproteomics. Encycl Metagen 2014;8:1-11.

65. Mukhtar S, Zaheer A, Aiysha D, Abdulla Malik K, Mehnaz S. Actinomycetes: a source of industrially important enzymes. J Proteomics Bioinform 2017;10:316-19.

66. Kar S, Ray RC. Statistical optimization of a-amylase production by Streptomyces erumpens MTCC 7317 cells in calcium alginate beads using response surface methodology. Pol J Microbiol 2008;57:49-57.

67. Yang $\mathrm{CH}$, Liu P. Purification and properties of a maltotrioseproducing alpha-amylase from thermobifida fusca. Enzyme Microb Technol 2004;35:254-60.

68. Bentley SD, Chater KF, Cerdeno Tarraga AM, Challis GL, Thomson NR, et al. Complete genome sequence of the model actinomycete Streptomyces coelicolor A3. Nature 2002; 417:141-7.

69. Wietzorrek A, Bibb M. A novel family of proteins that regulates antibiotic production in streptomycetes appears to contain an OmpR-like DNA-binding fold. Mol Microbiol 1997;25:1181-4.

70. Habbeche A, Saoudi B, Jaouadi B, Haberra S, Kerouaz B. Purification and biochemical characterization of a detergentstable keratinase from a newly thermophilic actinomycete Actinomadura keratinilytica strain Cpt29 isolated from poultry compost. J Biosci Bioeng 2014;117:413-21.

71. Zhang F, Chen JJ, Ren WZ, Nie GX, Ming H. Cloning, expression and characterization of an alkaline thermostable GH9 endoglucanase from Thermobifida halotolerans YIM $90462 \mathrm{~T}$. Biores Technol 2011;102:10143-6.

72. El-Sersy NA, Abd-Elnaby H, Abou-Elela GM, Ibrahim HAH, ElToukhy NMK. Optimization, economization and characterization of cellulose produced by marine Streptomyces ruber. Afr J Biotechnol 2010;9:6355-64.

73. Priya BS, Stalin T, Selvam K. Efficient utilization of xylanase and lipase producing thermophilic marine actinomycetes (Streptomyces albus and Streptomyces hygroscopicus) in the 
production of ecofriendly alternative energy from waste. Afr J Biotechnol 2012;11:14320-5.

74. Brzezinski R, Dery CV, Beaulieu C. Thermostable xylanase DNA protein and methods in use," USA patent; 1999. p. 5871730.

75. Taibi Z, Saoudi B, Boudelaa M, Trigui H, Belghith H, Gargouri A et al. Purification and biochemical characterization of a highly thermostable xylanase from Actinomadura sp. strain Cpt20 isolated from poultry compost. Appl Biochem Biotechnol 2012;166:663-79.

76. Aly MM, Tork S, Al-Garni SM, Nawar L. Streptomyces exfoliates LP10 isolated from oil contaminated soil. Afr J Microbiol Res 2012;6:1125-37.

77. Beyer M, Diekmann H. The chitinase system of Streptomyces sp. ATCC 11238 and its significance for fungal cell wall degradation. Appl Microbiol Biotechnol 1985;23:140-6.

78. Gooday GW. The ecology of chitin decomposition. Adv Microb Ecol 1990;11:387-430.

79. Taechowisan T, Peberdy JF, Lumyong S. Isolation of endophytic actinomycetes from selected plants and their antifungal activity. World J Microbiol Biotech 2003;19:381-5.

80. Usuki H Nitoda, Okuda T Kanzaki H. Screening and partial characterization of inhibitors of insect. Beta-Nacetylglucosaminidase. J Pesticide Sci 2006;31:41-6.

81. Jacob N, Poorna CA, Prema P. Purification and partial characterization of polygalacturonase from Streptomyces lydicus. Biores Technol 2008;99:66976701.

82. Janaki T. Keratinase activity (Feather) of streptomyces cacaoi subsp. cacaoi-M20. Int J Pharma Sci Res 2016;1:25-7.

83. Reading C, Cole M. Clavulanic acid: a beta-lactamase-inhibiting beta-lactam from Streptomyces clavuligerus. Antimicrobial Agents Chemother 1977;11:852-7.

84. Goodfellow M, Williams ST. Ecology of actinomycetes. Ann Rev Microbiiol 1983;37:189-216.

85. Newman DJ, Cragg GM. Natural products as sources of new drugs over the $30 \mathrm{y}$ from 1981 to 2010. J Nat Prod 2010;75:311-35.

86. Goodfellow M, Fiedler HP. A guide to successful bioprospecting: informed by actinobacterial systematics. Antonie Van Leeuwenhoek 2010;98:119-42.

87. Lazzarini A, Cavaletti L, Toppo G, Marinelli F. Rare genera of actinomycetes as potential producers of new antibiotics. Antonie Van Leeuwenhoek 2000;78:399-405.

88. Watve MG, Tickoo R, Jog MM, Bhole BD. How many antibiotics are produced by the genus Streptomyces? Arch Microbiol 2001;176:386-90.

89. Bérdy J. Are actinomycetes exhausted as a source of secondary metabolites? Biotechnologia 1995;7:13-34.

90. Wink JM, Kroppenstedt RM, Ganguli BN, Nadkarni SR, Schumann P, Seibert G, et al. Three new antibiotic producing species of the genus Amycolatopsis, Amycolatopsis balhimycina sp. nov., A. tolypomycina sp. nov., A. vancoresmycina sp. nov., and description of Amycolatopsis keratiniphila subsp. keratiniphila subsp. nov. and A. keratiniphila subsp. Mnogabecina subsp. nov. Syst Appl Microbiol 2003;26:38-46.

91. Tan G, Robinson S, Lacey E, Brown R, Kim W, Goodfellow M. Amycolatopsis regifaucium sp. nov., a novel actinomycete that produces kigamicins. Int J Syst Evol Microbiol 2007;57:2562-7.

92. Jensen P, Williams P, Zeigler L, Fenical W. Secondary metabolite production in marine actinomycetes of the Speciesspecific genus Salinispora. Appl Environ Microbiol 2007;73:1146-52.

93. Goodfellow M, Kumar Y, Labeda DP, Sembiring L. The Streptomyces violaceusniger clade: a home for streptomycetes with rugose ornamented spores. Antonie Van Leeuwenhoek 2007;92:173-99.

94. Jensen PR. Linking species concepts to natural product discovery in the post-genomic era. J Ind Microbiol Biotechnol 2010;37:219-24.

95. Ward AC, Goodfellow M. Phylogeny and functionality: taxonomy as a roadmap to genes. In: Microbial diversity and bioprospecting. A. T. Bull. Washington, D. C.: ASM Press; 2004 p. 288-313.

96. Oliynyk M, Samborskyy M, Lester JB, Mironenko T, Scott N Dickens $\mathrm{S}$, et al. Complete genome sequence of the erythromycin-producing bacterium saccharopolyspora erythraea NRRL 23338. Nat Biotechnol 2007;25:447-53.

97. Weinstein MJ, Luedemann GM, Oden EM, Wagman GH, Rosselet JP, Marquez, et al. Gentamicin, a new antibiotic complex from Micromonospora. J Med Chem 1963;6:463-4.

98. Wagman GH, Weinstein MJ. Antibiotics from Micromonospora. Annu Rev Microbiol 1980;34:537-57.

99. Jin ZH, Lin JP, Xu ZN, Cen PL. Improvement of industry-applied rifamycin B-producing strain, Amycolatopsis mediterranei, by rational screening. J Gen Appl Microbiol 2002;48:329-34.

100. Somma S, Gastaldo L, Corti A. Teicoplanin, a new antibiotic from actinoplanes teichomyceticus sp. nov. Antimicrob Agents Chemother 1984;26:917-23.

101. Jung HM, Jeya M, Kim SY, Moon HJ, Kumar Singh R, Zhang YW, et al., Biosynthesis, biotechnological production, application of teicoplanin: current state and perspectives. Appl Microbiol Biotechnol 2009;84:417-28.

102. Palanichamy V, Aachhari H, Mitra B, Reddy N. Optimization of cultivation parameters for growth and pigmen production by streptomyces spp. isolated from marine sediment and rhizosphere soil. IJPAES 2011;1:2231-4490.

103. Goodwin TW, Briton G. Distribution and analysis of carotenoids. Plant Pigments. Academic Press: London, United Kingdom; 1980.

104. Klein Marcuschamer D, Ajikumar PK, Stephanopoulos G. Engineering microbial cell factories for biosynthesis of isoprenoid molecules: beyond lycopene. Trends Biotechnol 2007;25:417-24.

105. Krinsky NI, Johnson EJ. Carotenoid actions and their relation to health and disease. Mol Aspects Med 2005;26:459-516.

106. Young AJ, Lowe GM. Antioxidant and pro-oxidant properties of carotenoids. Arch Biochem Biophys 2001:385:20-7.

107. Nawani NN. Diversity of chitinases of bacterial origin. $P h . D$. Thesis. University of Pune. Pune India; 2002.

108. Collins CH, Lyne PM, Granje JM. Microbiological methods Butterworth and Heinemann publishers; 1995

109. Kanavade VL. Use of bio-industrial waste for production of microbial biomass with potential in environmental management. Ph. D. Thesis, University of Pune, India; 2003.

110. Williams ST, Wellington EMH. Actinomycetes Ch. In: Methods of soil analysis. part 2. chemical and microbiological properties. America Inc Pub Madison Wisconsin USA 1982;45:969-87.

111. Shejul MS. Studies on heterotrophic filamentous procaryotes from aquatic habitats. Ph. D. Thesis, University of Pune India; 1998.

112. Zhang W, Li Z, Miao X, Zhang F. The screening of antimicrobial bacteria with diverse novel nonribosomal peptide synthetase (NRPS) genes from South China sea sponges. Mar Biotechnol (NY) 2009;11:346-55.

113. Selvameenal L, Radhakrishnan M, Balaraghunathan $R$ Antibiotic pigment from desert soil actinomycetes; biological activity, purification and chemical screening. Indian J Pharm Sci 2009;71:499-504.

114. Lechevalier MP. Ecological associations involving actinomycetes. In: Actinomycetes Stuttgart: Gustav Fischer Verlag; 1981. p. 159-66.

115. Zaitlin B, Clayton G, Parkinson D, Turkington K. Streptomyces halstedii and overall actinomycete communities in agricultural soil. Appl Soil Ecol 2004;26:53-62.

116. Lee JY, Hwang BK. Diversity of antifungal actinomycetes in various vegetative soils of Korea. Can J Microniol Rev Can Microbiol 2002;48;407-17.

117. Strzelczyk E, Leniarska V. Production of B group vitamins by mycorrhizal fungiand actinomycetes isolated from the root zone of pine (Pinus silvestris L.). Plant Soil 1985;86:387-94.

118. Black MC, Beute MK. Soil components that affect severity of Cylindrocladium black rot on peanuts. Plant Disease 1985;69:36-9.

119. Goodfellow M, Williams ST, Mordarski M. Actinomycetes in biotechnology. Academic Press, London; 1988. p. 461-82.

120. Lemmel SA, Heimsch RC, Edwards LL. Optimizing the continuous production of Candida utilis and Saccharomycopsis fibuligera on potato processing waste water. Appl Env Microbiol 1979;37:227-33. 
121. Fairbairn DA, Priest FG, Stark JRS. Extracellular amylase synthesis by Streptomyces limosus. Enz Microbi Technol 1986;8:89-92.

122. Shete HG. Cyanide degradation by streptomyces phacoviridae and Micromonospora braunna isolated from garden soil. M. Phil dissertation, University of Pune, India; 1995.
123. Goodfellow M, Cross T. Classification. In: The biology of actinomycetes. Academic Press, London; 1984. p. 7-164.

124. MacKenzie CR, Bilous D, Johnson KG. Sterptomyces flavogriseus cellulose: evaluation under various hydrolysis conditions. Biotechnol Bioengin 1984;26:590-4. 